\title{
Effect of Different Spacing and Urea Application Rates on Fruit Nutrient Composition, Growth and Yield of Tomato in Derived Savannah Vegetation of Kogi State, Nigeria
}

\author{
S. K. Ogundare*, J. A. Oloniruha, F. G. Ayodele, I. A. Bello \\ College of Agriculture, Division of Agricultural Colleges, Ahmadu Bello University, Kabba, Nigeria \\ Email: "drogundarekayode@yahoo.com
}

Received 22 July 2015; accepted 1 September 2015; published 4 September 2015

Copyright (C) 2015 by authors and Scientific Research Publishing Inc.

This work is licensed under the Creative Commons Attribution International License (CC BY). http://creativecommons.org/licenses/by/4.0/

(c) (i) Open Access

\begin{abstract}
Experiments were located at Lower Niger River Basin Development Authority, Ejiba and Horticultural Section College of Agriculture, Kabba in 2014 cropping season to investigate the effect of different spacing and urea application rates on fruit nutrient composition, growth and fruit yield of tomato in derived savanna vegetation of Nigeria. Field experiments were arranged in a randomized complete block design in factorial fashion with three replications. The row spacing were $75 \times$ $40 \mathrm{~cm}\left(33,333\right.$ plant $\left.\cdot \mathrm{ha}^{-1}\right), 75 \times 50 \mathrm{~cm}\left(26,666\right.$ plant $\left.^{-h^{-1}}\right)$ and $75 \times 60 \mathrm{~cm}\left(22,222\right.$ plant $\left.^{-h} \mathrm{a}^{-1}\right)$ while $^{-1}$ the urea rates comprised control $\left(0 \mathrm{~kg}\right.$ urea $\left.\cdot \mathrm{ha}^{-1}\right), 54.3$ and $108.6 \mathrm{~kg}$ urea $\cdot \mathrm{ha}^{-1}$. Growth and yield parameters taken were as follows: average plant height, stem girth, leaf area $\left(\mathrm{m}^{2}\right)$ and yield per land area. Data were collected from ten randomly selected plants in each plot. The data were statistically analyzed using GENSTAT. The analysis of variance (ANOVA) was performed to find out the significance of variation among the treatments while the significant difference between mean treatments was separated using least significance Difference at $5 \%$ level of probability. The result obtained from this study indicated that urea application and spacing affected significantly growth parameters of tomato and yield per land area. It could be concluded that there was a significant increase in plant height, number of leaves, number of fruits per plant and final fruit weight of tomato as a result of urea fertilizer application at the rate of $108.6 \mathrm{~kg}$ urea/ha. However, this was not significantly better than plots with urea application at $54.8 \mathrm{~kg} / \mathrm{ha}$ in both Ejiba and Kabba. Row spacing of $75 \times 50 \mathrm{~cm}$ showed better performance in number of fruit and fruit yield per plots. Farmers in Ejiba and Kabba should apply urea at the rate of $54.8 \mathrm{~kg}$ per hectare and plant the crop at a row spacing of $75 \times 50 \mathrm{~cm}$ for optimum yield and for a more profitable production of tomato.
\end{abstract}

\footnotetext{
*Corresponding author.

How to cite this paper: Ogundare, S.K., Oloniruha, J.A., Ayodele, F.G. and Bello, I.A. (2015) Effect of Different Spacing and Urea Application Rates on Fruit Nutrient Composition, Growth and Yield of Tomato in Derived Savannah Vegetation of Kogi State, Nigeria. American Journal of Plant Sciences, 6, 2227-2233. http://dx.doi.org/10.4236/ajps.2015.614225
} 


\section{Keywords}

\section{Row, Spacing, Tomato, Urea, Application, Growth, Yield}

\section{Introduction}

Tomato (Lycopersicon lycopersicum) is one of the most important vegetables grown for their edible fruits. Tomato is cultivated in Nigeria with an annual production of six million tonnes [1]. Tomato is an excellent source of vitamins, minerals, and antioxidants which help control cancer, health disease as well as improve the general health of man [2]. Nitrogen is the most critical element of plant growth. Vegetables growth is affected differently by various $\mathrm{N}$ sources [3]. Seedling growth (fresh or dry weight) was always more in nitrate than various reduced $\mathrm{N}$ sources [4]. Urea appeared to be the best source which gave the highest dry matter yield when four nitrogen sources $\left(\mathrm{NH}^{4+}, \mathrm{NH}_{4} \mathrm{OH}, \mathrm{NO}^{3-}\right.$ and urea) were compared [5]. Plant allocates different relative proportions of total $\mathrm{N}$ contents to leaves, stems and roots [6]. Large amount of $\mathrm{N}$ in the fertilizer reduces root infections [7].

Row spacing and plant population recommendations may vary for each location. Plant population is a production factor which affects light interception by plant canopy [8]. Plant height declines with reduced plant population. Stem sections of plants that receive more light usually tend to have slower elongation rates [9]. Fruits too close to the soil surface increase harvest losses [10]. Increased plant populations decreased the number of side branches [10]-[12], the fruit number per plant [13], the fruit yield per plant [11] [13], the fruit weight [11] and the harvest index [14] while fruit yield per hectare [10] was increased. Harvest index of smaller plants was less than for larger plants, but these smaller plants had little influence on total crop yield and harvest index [14]. The objective of this paper is to discuss the effect of different spacing's and urea application rates on fruit nutrient composition, growth and fruit yield of tomato in derived savanna vegetation of Nigeria.

\section{Materials and Methods}

Experiments were located at Lower Niger River Basin, Ejiba and Horticultural Section, College of Agriculture, Kabba in 2014 cropping season. Ejiba is located on latitude $8^{\circ} 18^{\prime} \mathrm{N}$ and longitude $50^{\circ} 39^{\prime} \mathrm{E}$ and Kabba is on latitude $07^{\circ} 35^{\prime} \mathrm{N}$ and longitude $06^{\circ} 08^{\prime} \mathrm{E}$ in the Southern Guinea Savannah Agro Ecological Zone of Nigeria. The soil at Ejiba is an ultisol, while that of Kabba is a gleysol [15] [16]. In the study areas, rainfall is monomodal and span from April to September.

Field experiments were arranged in a randomized complete block design in factorial fashion with three replications. The row spacing were $75 \times 40 \mathrm{~cm}\left(33,333\right.$ plant $\left.^{-h^{-1}}\right), 75 \times 50 \mathrm{~cm}\left(26,666\right.$ plant $\left.^{-1} \mathrm{ha}^{-1}\right)$ and $75 \times 60 \mathrm{~cm}$ $\left(22,222 \mathrm{plant} \cdot \mathrm{ha}^{-1}\right)$ while the urea rates comprised control $\left(0 \mathrm{~kg}\right.$ urea $\left.\cdot \mathrm{ha}^{-1}\right), 54.3$ and $108.6 \mathrm{~kg}$ urea $\cdot \mathrm{ha}^{-1}$. The net plot size measured $5.0 \times 4.0 \mathrm{~m}$. Half $\mathrm{N}$ and full $50 \mathrm{~kg} \cdot \mathrm{ha}^{-1} \mathrm{P}_{2} \mathrm{O}_{5}(24.6 \mathrm{~kg} \mathrm{P})$ was applied as a basal dose and remaining half $\mathrm{N}$ was applied at flowering.

The seeds were obtained at National Horticultural Research Institute of Nigeria (NIHORT) Ibadan. The seedling was raised in a nursery bed of $3 \times 4 \mathrm{~m}^{2}$. The seed were sown by drilling method. The nursery bed was watered and also kept free of weeds. Palm fronts were used in preventing directs sun rays on the seedlings. Karate was used in controlling insects in the nursery at the rate of $100 \mathrm{ml}$ per 20 litre of water. The seedlings were nurtured till they attain the age of 3 weeks old and transplanted to the field using ball of earth method during transplanting at varying spacing. Seedlings were transplanted by hand on 27 April, 2014. Before transplanting, a composite soil sample was taken from $0-15 \mathrm{~cm}$ of the experimental field and analyzed for selected physical and chemical properties [17]. The proximate analysis of the fruit was also assessed. Fruit samples were collected on per plot basis, and dried in an oven at $65^{\circ} \mathrm{C}$ till constant weight was obtained. The dried fruit samples were separately ground with a Wiley mill, and passed through a $0.5 \mathrm{~mm}$ sieve for tissue analysis. Total $\mathrm{N}$ was analyzed by the micro-Kjeldahl procedure as described by [18] and crude protein was obtained by multiplying the total $\mathrm{N}$ by a factor of 6.25. Concentrations of nutrient were expressed on the basis of percentage dry fruit material.

Ten plants were randomly selected and harvested at maturity from the second and third rows. In this plants using, plant height, number of branches per plant, fruit number per plant, yield were researched. Fruit yield was calculated over all plants in the plot. 


\section{Results and Discussion}

The properties of the soils at the sites of the experiment are shown in Table 1 . The soils are sand loam and sand clay loam in Ejiba and Kabba respectively. Soil of Ejiba is more acidic (5.74) when compared with the soil of Kabba (6.3). Both soils are high in bulk density. Organic matter, total N, available phosphorus (P) and exchangeable potassium (K) were low. Exchange Mg though low in soil of Ejiba, it was adequate in soil of Kabba. The nutrients present in the soils are expected not to meet the growing need of tomato in the study area.

Urea rate and row spacing influenced plant height of tomato significantly. Plant height increased with decreased spacing in tomato (Table 2). Maximum plant height was recorded at row spacing of $30 \mathrm{~cm}$ while the least height occurred in tomato spaced at $50 \mathrm{~cm}$ row in both locations. The result was similar to [19] [20] on soybean and [21] on pepper. As urea rate increased, plant height also increased (Table 2). Similar results were by [22] and [23]. The urea rate and row spacing interaction effects, maximal values were measured at spacing of $75 \times 40 \mathrm{~cm}$ with urea application rate of $54.3 \mathrm{~kg} / \mathrm{ha}$ in both location.

Stem girth was significantly affected by the treatments applied in both Kabba and Ejiba. Crop grown in Ejiba were remarkably shorter than tomato grown in Kabba. This could be due to variation in soil nutrients compositions of the locations. The thickest plants were recorded in plant spaced $75 \times 50 \mathrm{~cm}$, while the thinnest plant occurred in plots spaced at $75 \times 40 \mathrm{~cm}$. The finding was in line with the results of [24]. Urea application influenced stem girth increase relative to control. The thickest stem were observed in tomato treated with $108.6 \mathrm{~kg}$ urea per ha in Kabba, but plots treated with $54.3 \mathrm{~kg} /$ ha urea produced the thickest plant in Ejiba. All these were significantly better than the control. Among the urea rate and spacing interaction effects, tomato spaced at $40 \mathrm{~cm}$ with no urea application produced the thinnest plant, while the most produced stem girth occurred in plots with $50 \mathrm{~cm}$ row spacing and $108.6 \mathrm{~kg} /$ ha urea fertilizer at both locations.

The results of mean branch number and number of leaves produced in tomato planted at different intra row spacing were presented in (Table 2). Wider intra row spacing gave significant higher number of branches and number of leaves in Kabba and Ejiba. The better performance of the wider spaced plant could be attributed to better nutrients supplied and wider surface area exposed to by the crop which gave more opportunity of space to the crops. The result of this study is in agreement with that of [25] who reported increased number branches and leaves per plant. Number of branches and leaves increased with increased rate of urea. Plots amended with urea fertilizer were significantly better than the control in terms of number of branches and leaves produced. Urea rate at $108.6 \mathrm{~kg} /$ ha produced higher number of both branches and leaves in both locations. [26] [27] found that tomato seedlings grown with high $\mathrm{N}$ levels had enhanced growth and survival after transplanting. [28] Reported fertilizer containing nitrogen increases vegetative growth of tomato. Among the urea rate and intra spacing interaction effects, tomato spaced at $30 \mathrm{~cm}$ with no urea application produced the least number of branches and leaves, while the most produced branches and leaves occurred in plots with $50 \mathrm{~cm}$ intra spacing and $108.6 \mathrm{~kg} / \mathrm{ha}$ urea fertilizer at both locations.

Table 1. Physical and chemical properties of soil before the experiment.

\begin{tabular}{ccc}
\hline Properties & Ejiba & Kabba \\
\hline Sand (\%) & 68.6 & 60.3 \\
Clay (\%) & 16.4 & 21.6 \\
Silt (\%) & 19.0 & 18.1 \\
Soil texture & Sand loam & Sand clay loam \\
pH & 5.74 & 6.3 \\
Bulk density $\left(\mathrm{g} / \mathrm{cm}^{3}\right)$ & 1.46 & 1.31 \\
Total porosity (\%) & 43.8 & 40.8 \\
Organic matter (\%) & 1.83 & 2.1 \\
Total N (\%) & 0.14 & 0.19 \\
Available P (mg/kg) & 3.16 & 3.11 \\
Exchangeable K (cmol/kg) & 0.34 & 0.21 \\
Exchangeable Ca $(\mathrm{cmol} / \mathrm{kg})$ & 1.68 & 2.67 \\
Exchangeable $\mathrm{Mg}(\mathrm{cmol} / \mathrm{kg})$ & 1.43 & 3.57 \\
\hline
\end{tabular}


Spacing has no significant effect on nutrient composition of tomato fat (\%), fiber content (\%), protein (\%) and vit. C (mg/100g) (Table 3). Application of urea at different rates increased the content of protein, carbohydrate over the control. Plots treated with urea at $108.6 \mathrm{~kg} / \mathrm{ha}$ produced the highest value of fat (\%), fiber content and protein (\%) in both location values of Vit. C was inconsistent. The results show that there were no significant

Table 2. Effect of different spacing's and urea application rates on growth characters of tomato.

\begin{tabular}{|c|c|c|c|c|c|c|c|c|}
\hline \multirow{2}{*}{ Treatment } & \multicolumn{2}{|c|}{ Plant height } & \multicolumn{2}{|c|}{ Stem girth } & \multicolumn{2}{|c|}{ Branches } & \multicolumn{2}{|c|}{ No of leaves } \\
\hline & Kabba & Ejiba & Kabba & Ejiba & Kabba & Ejiba & Kabba & Ejiba \\
\hline \multicolumn{9}{|l|}{ Spacing } \\
\hline S1 & 1.64 & 1.38 & 0.23 & 0.16 & 6.66 & 6.13 & 16.8 & 19.2 \\
\hline S2 & 1.52 & 1.44 & 0.28 & 0.20 & 7.84 & 5.44 & 21.8 & 23.3 \\
\hline S3 & 1.48 & 1.58 & 0.29 & 0.23 & 8.44 & 7.22 & 27.4 & 30.4 \\
\hline LSD & 0.20 & 0.09 & 0.02 & 0.04 & 1.24 & 1.34 & 6.44 & 8.42 \\
\hline \multicolumn{9}{|l|}{ Urea rate } \\
\hline UR1 & 1.49 & 1.36 & 0.18 & 0.22 & 4.20 & 5.86 & 14.4 & 16.3 \\
\hline UR2 & 1.52 & 1.48 & 0.22 & 0.26 & 6.14 & 7.11 & 19.3 & 20.4 \\
\hline UR3 & 1.58 & 1.49 & 0.24 & 0.24 & 6.16 & 6.61 & 20.2 & 21.4 \\
\hline LSD & 0.46 & 0.04 & 0.03 & 0.03 & 1.24 & 0.96 & 4.48 & 3.61 \\
\hline \multicolumn{9}{|c|}{ Spacing $\times$ urea rate } \\
\hline S1UR1 & 1.32 & 1.28 & 0.14 & 0.17 & 4.34 & 5.11 & 14.6 & 15.1 \\
\hline S1UR2 & 1.32 & 1.30 & 0.22 & 0.23 & 6.64 & 6.74 & 15.4 & 15.4 \\
\hline S1UR3 & 1.37 & 1.32 & 0.20 & 0.22 & 6.23 & 6.33 & 16.6 & 17.3 \\
\hline S2UR1 & 1.34 & 1.31 & 016 & 0.24 & 5.21 & 5.78 & 15.8 & 16.2 \\
\hline S2UR2 & 1.41 & 1.43 & 0.19 & 0.20 & 7.32 & 6.88 & 19.4 & 21.4 \\
\hline S2UR3 & 1.47 & 1.57 & 0.24 & 0.22 & 6.31 & 6.13 & 20.2 & 21.6 \\
\hline S3UR1 & 1.28 & 1.32 & 0.16 & 0.20 & 4.98 & 5.11 & 16.9 & 17.4 \\
\hline S3UR2 & 1.42 & 1.48 & 0.24 & 0.25 & 6.88 & 7.12 & 21.4 & 23.4 \\
\hline S3UR3 & 1.49 & 1.55 & 0.24 & 0.24 & 7.02 & 7.32 & 21.0 & 22.9 \\
\hline LSD & 0.09 & 0.12 & 0.04 & 0.04 & 1.24 & 0.54 & 3.74 & 4.61 \\
\hline
\end{tabular}

$\mathrm{S}=$ (Spacing), UR = (Urea fertilizer).

Table 3. Effect of different spacing and urea application rate on nutrients composition of tomato.

\begin{tabular}{|c|c|c|c|c|c|c|c|c|}
\hline \multirow{2}{*}{ Treatment } & \multicolumn{2}{|c|}{$\%$ Fat } & \multicolumn{2}{|c|}{ Fiber content (\%) } & \multicolumn{2}{|c|}{ Protein (\%) } & \multicolumn{2}{|c|}{ Vit. C Mg/100g } \\
\hline & Kabba & Ejiba & Kabba & Ejiba & Kabba & Ejiba & Kabba & Ejiba \\
\hline \multicolumn{9}{|l|}{ Spacing } \\
\hline S1 & 5.91 & 6.17 & 4.61 & 5.63 & 19.6 & 18.8 & 0.36 & 0.59 \\
\hline S2 & 5.95 & 5.46 & 4.81 & 4.70 & 21.2 & 19.6 & 0.40 & 0.40 \\
\hline S3 & 5.45 & 5.64 & 5.73 & 4.66 & 19.2 & 21.5 & 0.47 & 0.50 \\
\hline LSD & ns & ns & ns & ns & ns & ns & ns & ns \\
\hline \multicolumn{9}{|l|}{ Urea rate } \\
\hline UR1 & 5.7 & 5.8 & 5.67 & 5.69 & 19.6 & 20.9 & 0.49 & 0.44 \\
\hline UR2 & 6.3 & 6.3 & 4.63 & 5.58 & 21.3 & 22.2 & 0.40 & 0.42 \\
\hline UR3 & 6.9 & 6.6 & 4.72 & 6.61 & 12.1 & 19.8 & 0.46 & 0.52 \\
\hline LSD & ns & ns & ns & ns & Ns & ns & ns & ns \\
\hline Spacing $\times$ urea rate & ns & ns & ns & ns & ns & ns & ns & ns \\
\hline
\end{tabular}

$\mathrm{S}=$ (Spacing), UR $=$ (Urea fertilizer) 
Table 4. Effect of different spacings and urea application rates on yield component of tomato.

\begin{tabular}{|c|c|c|c|c|c|c|c|c|}
\hline \multirow{2}{*}{ Treatment } & \multicolumn{2}{|c|}{ Fruit length (cm) } & \multicolumn{2}{|c|}{ Fruit weight (g) } & \multicolumn{2}{|c|}{ Number of fruits } & \multicolumn{2}{|c|}{ Fruit yield/plot } \\
\hline & Kabba & Ejiba & Kabba & Ejiba & Kabba & Ejiba & Kabba & Ejiba \\
\hline \multicolumn{9}{|l|}{ Spacing } \\
\hline S1 & 3.38 & 4.22 & 46.1 & 49.4 & 20.6 & 23.6 & 14.6 & 14.4 \\
\hline S2 & 4.89 & 4.83 & 71.4 & 78.7 & 30.4 & 31.0 & 22.3 & 22.5 \\
\hline S3 & 5.33 & 4.53 & 69.4 & 74.4 & 31.6 & 30.6 & 22.4 & 22.2 \\
\hline LSD & 0.49 & 0.34 & 3.64 & 5.78 & 2.24 & 2.62 & 2.98 & 3.63 \\
\hline \multicolumn{9}{|l|}{ Urea rate } \\
\hline UR1 & 3.67 & 3.01 & 24.1 & 26.4 & 14.4 & 16.4 & 11.6 & 13.4 \\
\hline UR2 & 4.76 & 4.4 & 61.5 & 53.5 & 30.6 & 29.4 & 23.3 & 21.6 \\
\hline UR3 & 5.11 & 4.22 & 63.0 & 49.4 & 35.3 & 34.7 & 27.4 & 24.6 \\
\hline LSD & 0.45 & 0.23 & 3.99 & 2.41 & 3.62 & 2.13 & 5.17 & 4.44 \\
\hline \multicolumn{9}{|c|}{ Spacing $\times$ urea rate } \\
\hline S1UR1 & 3.22 & 3.11 & 43.41 & 32.4 & 28.6 & 21.4 & 13.9 & 14.6 \\
\hline S1UR2 & 3.44 & 3.21 & 53.61 & 41.6 & 33.5 & 35.6 & 18.7 & 16.8 \\
\hline S1UR3 & 3.56 & 3.34 & 58.62 & 46.4 & 36.0 & 34.2 & 20.0 & 21.4 \\
\hline S2UR1 & 3.36 & 3.14 & 60.13 & 54.6 & 36.3 & 35.3 & 21.8 & 20.4 \\
\hline S2UR2 & 4.74 & 4.31 & 59.14 & 48.4 & 34.2 & 33.3 & 22.2 & 21.3 \\
\hline S2UR3 & 5.12 & 3.99 & 57.66 & 46.7 & 32.3 & 33.4 & 19.6 & 20.4 \\
\hline S3UR1 & 4.21 & 3.41 & 61.34 & 54.8 & 33.3 & 29.4 & 20.3 & 21.4 \\
\hline S3UR2 & 5.37 & 4.44 & 58.67 & 54.3 & 31.6 & 31.4 & 20.5 & 22.4 \\
\hline S3UR3 & 5.21 & 4.66 & 56.14 & 56.9 & 30.1 & 33.6 & 20.1 & 20.6 \\
\hline LSD & 0.56 & 0.68 & 2.53 & 5.11 & 2.29 & 2.84 & 2.23 & 3.81 \\
\hline
\end{tabular}

$\mathrm{S}=$ (Spacing), $\mathrm{UR}=$ (Urea fertilizer).

interactions between row spacing's and urea application rates in these experiments at both locations. The critical role nitrogen plays in the nutrition of crop especially and quality of its fruit was obvious in this experiment. In the synthesis of protein and carbohydrate, need optimum nitrogen [29].

The yield parameters of tomato planted at different row spacing are shown in Table 4. Plots with increased row spacing (50 and $60 \mathrm{~cm}$ ) were better than plots with closed row spacing $(40 \mathrm{~cm})$ in terms of fruit length, fruit weight, number of fruit and fruit yield. The result of these studies conformed to the result of [30] who reported that wider intra row spacing minimized competition for nutrients, water and radiation which in turn favoured fruit sizes. According to [31] fruit size determines the consumer preference in tomato crop. [32] obtained higher tomato fruit weight with wider intra row spacing. Fruit length, fruit weight, number of fruits and fruit yield increased with increased rate of urea. The highest increase was observed in plots treated with $108.6 \mathrm{~kg}$ urea, while the control plots recorded the least value of fruit length, fruit weight, and number of fruits per plant and fruit yield per hectare. The results consisted to the finding of [33]. As to the effects of urea application rate and intra row spacing interactions, highest fruit yield was observed in crop spaced at $40 \mathrm{~cm} \times$ urea rate of $54.3 \mathrm{~kg} / \mathrm{ha}$ in Kabba and highest fruit yield was in plots treated with spacing of $50 \mathrm{~cm} \times$ urea rate of $54.3 \mathrm{~kg} / \mathrm{ha}$.

\section{Conclusion}

From the aforementioned discussion, it could be concluded that there was a significant increase in plant height, number of leaves, number of fruits per plant and final fruit weight of tomato as a result of urea fertilizer application at the rate of $108.6 \mathrm{~kg}$ urea/ha. However, this was not significantly better than plots with urea application at $54.8 \mathrm{~kg} / \mathrm{ha}$ in both Ejiba and Kabba. Row spacing of $75 \times 50 \mathrm{~cm}$ showed better performance in number of fruit and fruit yield per plots. Farmers in Ejiba and Kabba should apply urea at the rate of $54.8 \mathrm{~kg}$ per hectare and plant the crop at a row spacing of $75 \times 50 \mathrm{~cm}$ for optimum yield and for a more profitable production of tomato. 


\section{References}

[1] Idah, P.A., Ajigiri, E.S.A. and Yisa, M.G. (2007) Fruits and Vegetables Handling and Transportation in Nigeria. AU J.I, 10, 175-183. Department of Agriculture Engineering, Federal University of Technology, Minna.

[2] Antonio, I., Nigro, F. and Schenna, L. (2004) Control of Post Harvest Diseases of Fresh Vegetable by Application of Antagonistic Micro-Organism. In: Dris, R., Niskanen, R. and Jai, S.M., Eds., Crop Management and Postharvest Handling of Horticultural Products, 1-30.

[3] Ryle, G.J.A., Powel, C.E. and Gordon, A.J. (1978) Effect of Source of Nitrogen on the Growth of Fiskeby Soybean. The Carboneconomy of Whole Plants. Ann. Pot., 42, 637-648.

[4] Lahav, E., Harper, J.E. and Hugeman, R.H. (1976) Improved Soybean Growth in Urea with pH Buffered by a Carboxy Resin. Crop Science, 16, 325-328. http://dx.doi.org/10.2135/cropsci1976.0011183X001600030003x

[5] DeMooy, C.J., Pesek, J. and Spaldon, E. (1973) In: Caldwell, B.E., Ed., Soybeans: Improvement, Production and Uses, American Society ofAgronomy Inc., Madison, 267-273.

[6] DeJong, T.M. and Phillips, D.A. (1981) Nitrogen Stress and Apparent Photosynthesis in Symbiotically Grown Pisum sativum. Plant Physiology, 68, 309-313. http://dx.doi.org/10.1104/pp.68.2.309

[7] Dazzo, F.B. and Brill, W.J. (1978) Regulation by Fixed Nitrogen of Host-Symbiont Recognation in the RhizobiumClover Symbiosis. Plant Physiology, 62, 18-21. http://dx.doi.org/10.1104/pp.62.1.18

[8] Board, J. (2001) Reduced Lodging for Soybean in Low Plant Population Is Related to Light Quality. Crop Science, 41, 379-384. http://dx.doi.org/10.2135/cropsci2001.412379x

[9] Garrison, R. and Briggs, W.R. (1972) Internodal Growth in Localized Darkness. Botanical Gazette (Chicago), 133, 270-276. http://dx.doi.org/10.1086/336642

[10] Caliskan, S., Aslan, M., Uremis, I. and Caliskan, M.E. (2007) The Effect of Row Spacing on Yield and Yield Components of Full Season and Double Cropped Soybean. Turkish Journal of Agriculture and Forestry, 31, 147-154.

[11] Pawlowski, F., Jedruszczak, M. and Bojarcazyk, M. (1993) Yield of Soybean cv Polan on Loens Soil Depending in Row Spacing and Sowing Rate. Field Crop Abstracts, 46, 978.

[12] Ibrahim, S.A. and Hala, K. (2007) Growth, Yield and Chemical Constituents of Soybean (Glycin max L.) Plants as Affect by Plant Spacing under Different Irrigation Intervals. Research Journal of Agriculture and Biological Sciences, 3, 657-663.

[13] Shafshak, S.E., Serf, S.A. and Sharaf, A.E. (1989) Yield and Quality of Soybean as Affected by Population Density and Plant Distribution. Field Crop Abstracts, 42, 4312.

[14] Spaeth, C., Randall, H.C., Sinclair, T.R. and Vendeland, J.S. (1984) Stability of Soybean Harvest Index. Agronomy Journal, 76, 482-486. http://dx.doi.org/10.2134/agronj1984.00021962007600030028x

[15] Higgins, G.M. (1957) Preliminary Report on the Detailed Land, Soil and Contours Survey of River Rine Area of School of Agriculture, Kabba. Soil Survey Bulletin No.31, 28.p.

[16] Babalola, T.S. (2010) Land Evaluation Studies of Two Wetland Soil in Nigeria. Master's Thesis, Department of Crop, Soil and Environmental Sciences, University of Ado-Ekiti, Ado Ekiti, 141.

[17] Bray, R.H. and Kurtz, L.T. (1945) Determination of Total and Available Forms of Phosphorus in Soils. Soil Science, 59, 39-45. http://dx.doi.org/10.1097/00010694-194501000-00006

[18] IITA (1982) Automated and Semi-Automated Methods of Soil and Plant Analysis Manual, Series No.7. IITA, Ibadan.

[19] Christmas, E.P. (2002) Plant Populations and Seeding Rates for Soybeans. AY-217. Purdue University Cooperative Extension Service, West Lafayette.

[20] Yilmaz, N. (2003) The Effect of Different Seed Rates on Yield and Yield Components of Soybean (Glycine max L. Merill). Pakistan Journal of Biological Sciences, 6, 373-376. http://dx.doi.org/10.3923/pjbs.2003.373.376

[21] Ogundare, S.K. and Attah, E.S. (2013) Effect of Varying Intra-Row Spacing on the Growth and Yield of Pepper in Kabba, Kogi State, Nigeria. Nigerian Journal of Horticultural Science, 11, 49-52.

[22] Starling, M., Weaver, D. and Wood, W. (1998) Nitrogen Improves Yield of Late Planted Soybeans. Highlights of Agricultural Research, 45, 18-19.

[23] Seneviratne, G., Van Holm, L.H.J. and Ekanayake, E.M.H.G.S. (2000) Agronomic Benefits of Rhizobial Inoculant Use over Nitrogen Fertilizer Application in Tropical Soybean. Field Crops Research, 68, 199-203. http://dx.doi.org/10.1016/S0378-4290(00)00123-4

[24] Olaniyi, J.O., Akanbi, W.B., Adejumo, T.A. and Akande, O.G. (2010) Growth, Fruit Yield and Nutritional Quality of Tomato Varieties. African Journal of Food Science, 4, 398-402.

[25] Muhammad, A.A. and Muhammad, A. (2002) Influence of Mother Root Size and Plant Spacing on Carrot Seed Pro- 
duction. Journal of Resource Science, 13, 105-112.

[26] Liptay, A. and Nicholls, S. (1991) Nitrogen Supply during Green House Transplant Production Affects Subsequent Tomato Root Growth in This Field. Journal of the American Society for Horticultural Science, 118, 339-342.

[27] Melton, R.R. and Dufault, R.J. (1991) Nitrogen, Phosphorus and Potassium Fertility Regimes Affect Tomato Transplant Growth. HortScience, 26, 141-142.

[28] Ganmore-Neumann, R. and Kafkafi, U. (1980) Root Temperature and Percentage $\mathrm{NO}^{3-} / \mathrm{NH}^{4+}$ Effect on Tomato Plant Development: In Morphology and Growth. Agronomy Journal, 72, 758-761. http://dx.doi.org/10.2134/agronj1980.00021962007200050016x

[29] Upendra, M.S., Ramdane, D. and Bharat, S. (2000) Mineral Nutrition in Tomato. Food, Agriculture and Environment, 1, 176-183.

[30] Ahamd, A. and Singh, A. (2005) Effects of Staking and Raw-Spacing on the Yield of Tomato (Lycopersicon esculentum Mill.) Cultivar "Roma VF” in the Sokoto Fadama, Nigeria. Nigerian Journal of Horticultural Science, 10, 94-98.

[31] Resh, H.M. (2003) Hydroponic Food Production. 6th Edition, New Concept Press Publishing Co., Mahwah, 23-27.

[32] Muhammad, A. and Singh, A. (2007) Intra-Row Spacing and Pruning Effects on Fresh Tomato Yield in Sudan Savanna of Nigeria. Journal of Plant Sciences, 2, 153-161. http://dx.doi.org/10.3923/jps.2007.153.161

[33] Hozhbryan, M. (2013) Effects of Different Levels of Urea on the Growth and Yield of Tomato. JNAS Journal, 2, 1031-1035. 